\title{
PENGARUH SETING INTERIOR RUANG TUNGGU TERHADAP ATRIBUT KENYAMANAN PENGGUNA (Studi Kasus: Ruang Tunggu BRI)
}

\author{
Tri Susetyo Andadari ${ }^{1}$, Djoko Indrosaptono ${ }^{2}$, Suzanna Ratih Sari ${ }^{3}$ \\ Program Studi Arsitektur, Fakultas Teknik, Universitas Diponegoro Semarang \\ Jl. Prof. H. Soedarto S.H, Tembalang, Kec. Tembalang, Kota Semarang, Jawa Tengah 50275 \\ andadaritri@gmail.com
}

\section{Diterima: 22 Agustus 2019 Direvisi: 11 November 2019 Disetujui: 11 Nov 2019}

ABSTRAK. Perencanaan interior (ruang-dalam) diperlukan untuk memenuhi kebutuhan manusia sebagai subyek pengguna property. Namun kadang, perilaku manusia sebagai pengguna properti justru tidak sesuai dengan apa yang direncanakan oleh arsitek, sehingga menyebabkan beberapa masalah baru yang perlu dicarikan solusi. Penelitian ini bertujuan untuk mencari pengaruh seting interior ruang tunggu, terhadap atribut kenyamanan manusia sebagai pengguna ruang. Kenyamanan dibatasi hanya pada kenyamanan sirkulasi terhadap aspek lay out dan dimensi furnishing pada ruang tunggu BRI Ungaran. Penelitian ini bertujuan untuk mengkaji dan mengevaluasi, sejauh mana kesesuaian antara rencana seting ruang-dalam terhadap realita penggunanya, terutama dalam aspek lay out dan dimensi furnishing. Metode yang digunakan dalam penelitian ini adalah metode person centered mapping, dengan paradigma kuantitif, dan teknik analisis statistik deskripstif. Dimana hasil akhirnya menunjukkan bahwa seting tata ruang-dalam berpengaruh terhadap kenyamanan sirkulasi pengguna. Terdapat seting tata ruang-dalam yang salah yang menyebabkan banyaknya aktivitas pengguna yang tidak sesuai dengan perencanaan awal.

Kata kunci: Seting Interior, Ruang Tunggu, Kenyamanan

ABSTRACT. Interior design is needed to fulfill human needs as the subject of property users. Sometimes, human behavior does not match with the architect's design. It is causing some new problems that need a solution. The main comfort studied, especially in the convenience of circulation related to layout aspects and furnishings dimensions at BRI Ungaran's waiting room. The aims of this study to find the influence of waiting room interior settings on the comfort attributes of humans and to evaluate how far the interior setting plan matches the actual conditions in terms of the layout and furnishing dimensions. This study uses the quantitative paradigm, with the person-centered mapping method and descriptive statistical analysis techniques. The final results indicate some incompatibilities planning with the actual of the user's circulation. Some alternative designs are expected to be a solution to the problems encountered.

Keywords: Interior Settings, Waiting Room, Comfort

\section{PENDAHULUAN}

Desain interior atau biasa disebut tata ruangdalam suatu bangunan tergantung dari berbagai faktor, diantaranya adalah keinginan klien sebagai penentu tampilan akhir, fungsi dan kegunaan ruang, besaran ruang, ide desain, material yang digunakan, prediksi pengguna di masa datang, lay out, jenis dan dimensi furnishing dan lain-lain. Pada tahap akhir dari proses desain tata ruang-dalam, perlu adanya feed back, baik untuk desain bangunan yang identik pada masa depan sekaligus sebagai review apakah desain terbangun sudah bisa memenuhi fungsi sesuai standar tingkat kenyamanan.

Dipilihnya ruang tunggu BRI, berdasarkan fenomena yang ada, yang berhasil penulis tangkap yaitu banyaknya pengguna ruang yang melakukan aktivitas pada tempat yang tidak semestinya.

Tujuan penelitian ini adalah: (1) mengidentifikasi penyimpangan yang terjadi di lapangan terhadap aspek lay out dan dimensi furnishing pada seting ruang-dalam obyek penelitian; (2) Sebagai evaluasi terhadap perencanaan aspek lay out dan dimensi furnishing seting ruang-dalam pada obyek penelitian; (3) Mengetahui adanya pengaruh lay out dan dimensi furnishing seting ruangdalam, terhadap kenyamanan pengguna ruang, terutama pada kenyamanan sirkulasi.

\section{METODE PENELITIAN}

Metode yang dipakai dalam penelitian ini adalah metode person centered mapping dengan paradigma kuantitatif dengan analisis 
statistik deskriptif, untuk mendapatkan kecenderungan tertinggi dari variabel yang telah ditentukan. Disamping itu penelitian ini merupakan penelitian pasca huni dengan menggunakan metode post occupancy evaluation indikatif, yaitu upaya mengindikasi hambatan dan potensi lingkungan binaan dengan langkah-langkah metode pengumpulan datanya adalah evaluasi dokumen dan arsip, evaluasi pertanyaanpertanyaan dan wawancara terseleksi (Preiser et al., 1993).

Penelitian ini merupakan penelitian asosiatif, yaitu penelitian yang bertujuan untuk mengetahui hubungan antara dua variabel atau lebih yang terdiri dari variabel independen (variabel yang mempengaruhi) dan dependen (variabel yang dipengaruhi). Variabel independen dalam penelitian ini adalah seting ruang-dalam pada obyek penelitian yang dibatasi hanya pada aspek lay out dan dimensi furnishing. Sedangkan variabel dependennya adalah kenyamanan pengguna yang hanya dibatasi pada kenyamanan sirkulasi pengguna.

\section{Seting Interior Ruang Tunggu}

Menurut Haryadi dan Setyawan, istilah seting (setting) dipakai dalam kajian arsitektur lingkungan dan perilaku, dimana dalam hal ini menunjukkan pada hubungan antara ruang (lingkungan fisik spasial) dengan segala aktivitas individu/sekelompok individu dalam kurun waktu tertentu (Haryadi \& Setiawan, 1995).

Dalam hubungannya dengan perilaku manusia, Atkinson menyatakan bahwa kondisi lingkungan (seting) akan membentuk perilaku manusia, dan sebaliknya perilaku manusia akan membentuk lingkungannya. Hal ini disebabkan karena perilaku manusia adalah hasil interaksi secara terus menerus antara variabel pribadi dengan variabel lingkungan (Atkinson, 1983).

Ruang-dalam atau interior adalah volume tiga dimensi. Desainer interior memulai merancang volume kosong dan mengubahnya ke lingkungan yang berisi eksistensi manusia di dalamnya. Menurut Suptandar, ruangdalam atau interior adalah bagian dari bangunan yang dibatasi oleh lantai, dinding dan plafond. Dalam pelaksanaannya, disamping tiga komponen pembentuk ruang diatas terdapat elemen-elemen lain yang harus dipertimbangkan dalam proses desain yaitu pencahayaan dan penghawaan (Suptandar, 1982).
Desain interior oleh Suptandar (1982) dinyatakan sebagai karya seni yang mengungkapkan dengan jelas dan tepat tata kehidupan manusia dari suatu masa melalui media ruang. Ada beberapa elemen terkait dengan tata ruang-dalam, antara lain adalah material yang digunakan pada elemen pembentuk ruang-dalam, furnishing, besaran ruang, lay out, penghawaan dan pencahayaan. Pada penelitian ini, aspek yang diteliti pada obyek penelitian hanya dibatasi pada lay out dan dimensi furnishing dalam memberikan pengaruh pada kenyamanan sirkulasi dan aksesibilitas pengguna.

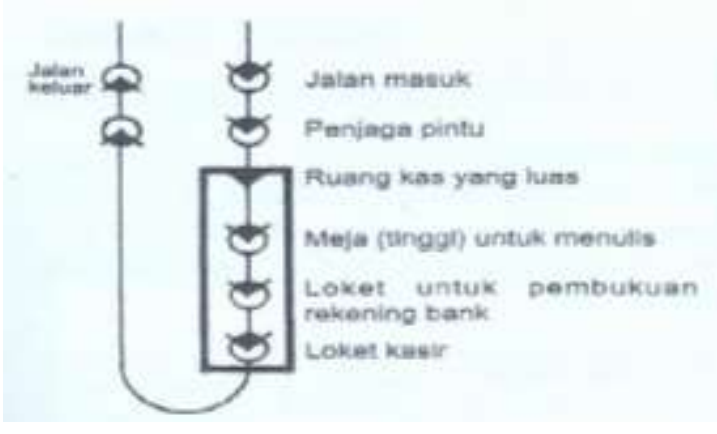

\section{Gambar 1. Jalur Nasabah Bank Menurut Neufert Arsitek Data Sumber: (Neufert, 2002)}

Di dalam Bank, pada ruang jalur nasabah bank, minimal harus terdapat ruang penjagaan pintu, ruang kas, meja untuk menulis, loket untuk pembukuan dan loket keluar-masuk (Neufert, 2002). Ruang tunggu Bank termasuk dalam salah satu kategori internal public space, yang bisa diartikan sebagai ruang pada fasilitas-fasilitas umum, dimana orang bisa atau boleh mengakses di dalamnya. Beberapa kebutuhan mendasar terkait dengan internal public space ini antara lain adalah comfortable atau kenyamanan, privacy dan kemudahan akses. Terkait kejenuhan pada ruang tunggu, Malkin menyebutkan "Few wait with pleasure. In fact, waiting tends to concentrate one"s attention on the detail of surrounding, making the presence or lack of good interior design more noticeable" (Malkin, 1992). Sehingga desain tata ruang-dalam harus dibuat senyaman mungkin untuk menunjang aktivitas pengguna, mengingat pada ruang tunggu, konsentrasi pengguna akan meningkat terhadap detail-detail interior suatu ruangan.

Lay out tata ruang-dalam berkaitan dengan sirkulasi dan urutan aktivitas yang diwadahi. Sirkulasi standard pada bank pada jalur nasabah seperti terlihat pada gambar 1 (Neufert, 2002). 
Standar dimensi furnishing pada ruang kantor, yang biasanya digunakan pada ruang tunggu bank, menurut Neufert Architect Data, untuk kursi tunggu minimal adalah $450 \times 450 \mathrm{~mm}$ sedangkan maximal adalah $800 \times 800 \mathrm{~mm}$ (Neufert, 2002). Sedangkan untuk meja tulis ukuran standar adalah $\pm 600 \times 1000 \times 740 \mathrm{~mm}$ (Neufert, 2002).

\section{Atribut Kenyamanan}

Atribut adalah kualitas lingkungan yang dirasakan sebagai pengalaman manusia yang merupakan hasil dari produk interaksi antara perilaku individu/kelompok dalam suatu organisasi dengan setingnya (Weisman, 1981).

\begin{tabular}{|l|l|l|}
\hline Item & Description & Dimension \\
\hline Lobby & Buffer zone area & $0.65 \mathrm{~m}^{2}$ \\
\hline & circulation & $150 \%$ \\
\hline Locket & standar & $3 \mathrm{~m}^{2}$ \\
\hline & circulation & $20 \%$ \\
\hline Ruang Antrean & Touch zone area & $0.28 \mathrm{~m}^{2}$ \\
\hline Lavatory & $1.5 \mathrm{~m} \mathrm{x} \mathrm{1.9m}$ \\
\hline \multicolumn{2}{|c|}{$\begin{array}{c}\text { Gambar 2. Standarisasi Ruang } \\
\text { Sumber: (Neufert, 2002) }\end{array}$}
\end{tabular}

Konsep tentang kenyamanan (comfort) sangat sulit untuk di definisikan karena lebih merupakan penilaian responsif individu (Oborne, 1995). Dalam kaitannya dengan rancangan ruang publik dan lansekap, Hakim menyebutkan kenyamanan ditentukan oleh beberapa unsur pembentuk, yaitu sirkulasi, iklim, aroma, bentuk, kebisingan, keamanan, kebersihan, keindahan dan penerangan (Hakim, 2012). Pada penelitian ini, kenyamanan yang dimaksud, hanya dibatasi pada kenyamanan sirkulasi, karena berkaitan dengan variabel seting ruang-dalam yang dipilih yaitu lay out dan dimensi furnishing.

Dari sudut pandang sirkulasi, Hakim menyebutkan bahwa kenyamanan dapat berkurang karena sirkulasi yang kurang baik, seperti tidak adanya pembagian ruang yang jelas untuk sirkulasi manusia dan kendaraan bermotor, atau tidak ada pembagian sirkulasi antara ruang satu dengan lainnya. Adapun definisi sirkulasi menurut Harris menyebutkan bahwa sirkulasi merupakan suatu pola lalu lintas atau pergerakan yang terdapat dalam suatu area atau bangunan $\mathrm{Di}$ dalam bangunan, suatu pola pergerakan memberikan keluwesan, pertimbangan ekonomis, dan fungsional (Harris, 1975). Sedangkan menurut Ching, sirkulasi merupakan tali yang terlihat dan menghubungkan ruang-ruang dalam suatu bangunan atau tali yang menghubungkan deretan ruang dalam dan ruang luar secara bersama-sama (Ching, 1979).

Terdapat 3 variabel penilaian sirkulasi, yaitu dimensi jalur sirkulasi, kejelasan orientasi dan penerapan elemen sirkulasi (signage). Signage sebagai elemen dasar yang memiliki fungsi utama sebagai alat komunikasi antar manusia dalam suatu bangunan atau lingkungan mengandung beberapa elemen penting, yaitu typography/teks, warna, symbol, panah dan pencahayaan.

\section{Behavior Setting}

Menurut Barker 1968 dalam (Adhitama, 2013), Behavior setting didefinisikan sebagai suatu kombinasi yang stabil antara aktivitas dengan tempat dengan kriteria seperti terdapat suatu aktivitas yang berulang berupa suatu pola perilaku, dengan tata lingkungan tertentu, membentuk suatu hubungan yang sama antar keduanya serta dilakukan pada periode waktu tertentu.

Dalam Behavior Mapping digambarkan dalam bentuk sketsa atau diagram mengenai suatu area dimana manusia melakukan berbagai kegiatannya, Sommer dalam Adhitama (2013). Tujuannya adalah untuk menggambarkan perilaku dalam peta, mengidentifikasikan jenis dan frekuensi perilaku, serta menunjukkan kaitan antara perilaku tersebut dengan wujud perancangan yang spesifik. Pemetaan perilaku dilakukan secara langsung pada saat dan tempat dimana dilakukan pengamatan. Terdapat dua cara melakukan pemetaan perilaku yakni:

\section{Place-centered mapping}

Teknik ini digunakan untuk mengetahui bagaimana manusia atau seketompok manusia memanfaatkan, menggunakan dan mengakomodasikan perilakunya dalam suatu waktu pada tempat tertentu.

\section{Person-centered mapping}

Teknik ini menekankan pada pergerakan manusia pada periode waktu tertentu, dimana teknik ini berkaitan dengan tidak hanya satu tempat atau lokasi akan tetapi beberapa tempat / lokasi.

\section{HASIL DAN PEMBAHASAN}

Penelitian ini menggunakan metode personcentered mapping dengan teknik pengambilan sampling menggunakan teknik acidental 
sampling. Dimana sample person sebagai pengguna ruang yang diamati adalah nasabah pada obyek penelitian, yang datang dan melakukan transaksi, baik tunai maupun non tunai, baik pada Customer Service maupun Teller, tanpa memandang latar belakang profesi, gender dan usia.

Waktu pengamatan dilakukan hanya pada hari kerja, pada jam kerja, yaitu pagi hari dari jam 08.30 WIB sampai dengan 12.00 WIB, dan siang hari yaitu pada pukul 12.00 WIB sampai dengan 15.00 WIB.

Jumlah sampel ditentukan dengan mempertimbangkan prinsip keterbatasan waktu, biaya, tenaga dan dilakukan sesuai waktu kegiatan (Mantra dalam Singarimbun (1992). Namun tetap sesuai dengan ketentuan untuk ukuran sampel yang layak dalam penelitian yaitu antara 30 sampai dengan 500 responden.

Kriteria pemilihan sampel $(\mathrm{N}=40)$ didasarkan pada nasabah yang mempunyai sifat homogen, yaitu yang datang dan beraktivitas di ruang tunggu, baik yang hendak bertransaksi dengan teller maupun customer sevice, pada jam kerja, baik laki-laki maupun perempuan.

\section{Elemen Lay Out Tata Ruang-Dalam}

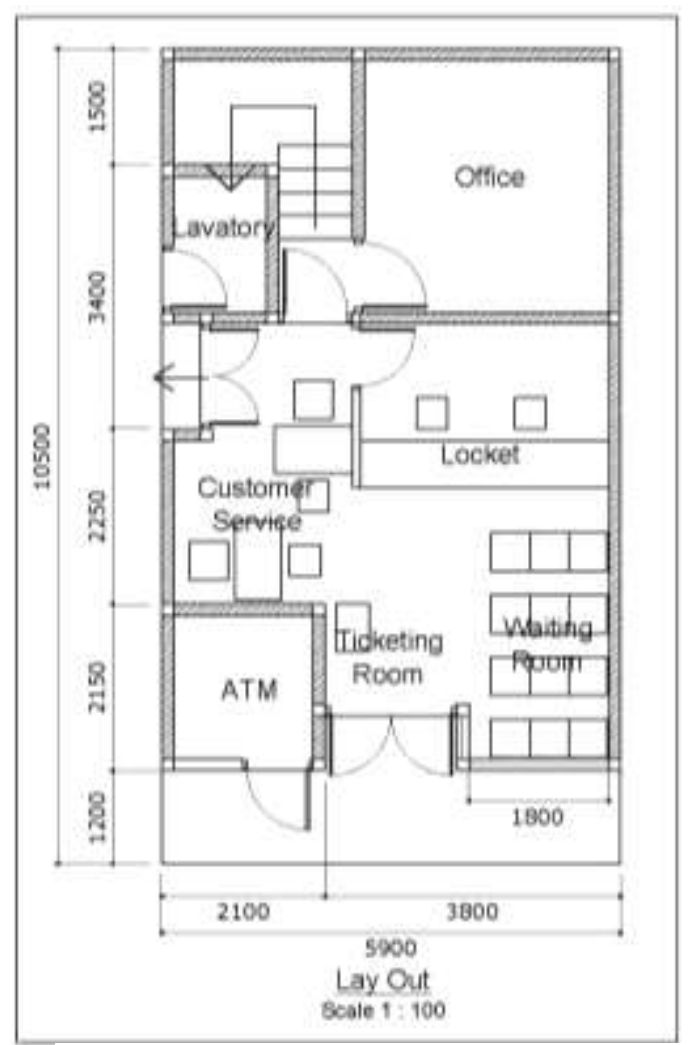

Gambar 3. Plan

Sumber: Analisis Pribadi (2019)
Berdasarkan observasi yang dilakukan pada obyek penelitian didapatkan lay out dan besaran ruang pada obyek penelitian, seperti pada gambar 3. Besaran ruang untuk zona privat sebesar $17 \mathrm{~m} 2$, zona semi publik $17 \mathrm{~m} 2$, zona service $3 \mathrm{~m} 2$ dan zona publik $14 \mathrm{~m} 2$. Besaran ruang lobby $3 \mathrm{~m} 2$, locket $17 \mathrm{~m} 2$, ruang antre 7,6 m2 dan lavatory $3 \mathrm{~m} 2$. Jlka dibandingkan dengan tabel Neufert Architect Data pada gambar 1, maka angka-angka besaran ruang yang didapat adalah melebihi dari angka standar minimun yang ditetapkan.

Berdasarkan hasil observasi lapangan, ratarata dalam 1 jam, pada obyek penelitian terdapat 18 nasabah. Dengan jumlah kursi pada ruang antre yang hanya 12 buah, maka bisa disimpulkan bahwa jumlah pengunjung melebihi kapasitas yang ada, walaupun dengan besaran ruang tunggu sebesar $7,6 \mathrm{~m} 2$, standar touch zone $0.28 \mathrm{~m} 2$ dan sirkulasi 20 $\%$, harusnya maximal bisa menampung 21 orang.

\section{Sirkulasi Pengguna}

Penentuan lay out pada suatu desain terkait dengan sirkulasi dan tata urutan aktivitas yang diwadahi. Oleh arsitek, pola sirkulasi yang diharapkan terjadi pada obyek penelitian, bisa dilihat pada bambar 4. Namun dari hasil observasi menunjukkan beberapa perubahan pola sirkulasi pengunjung seperti terlihat pada gambar 5. 


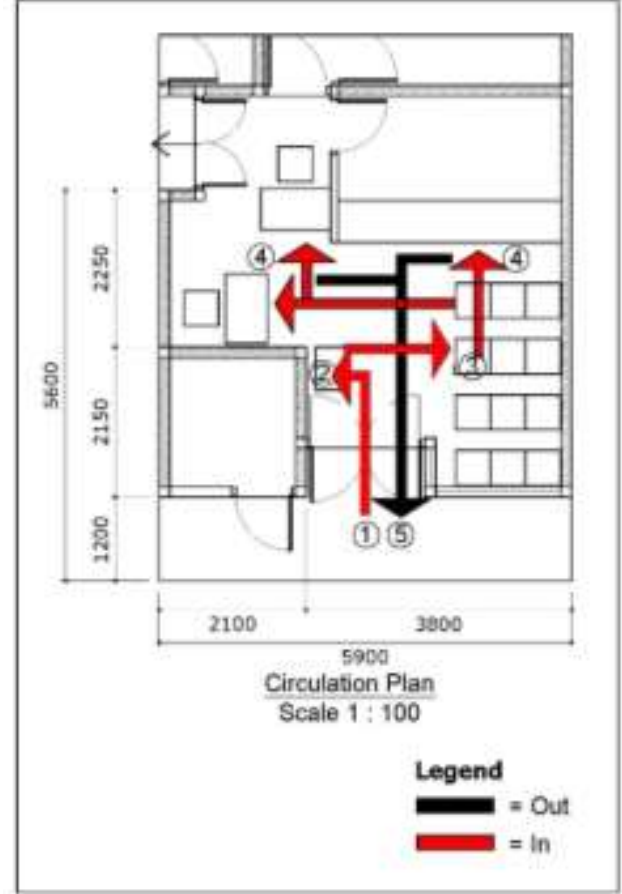

Gambar 4. Rencana Sirkulasi Sumber: Analisis Pribadi (2019)

Penyimpangan yang 1 seperti diilustrasikan pada gambar $5 \# 1$, terjadi pada kondisi kursi tunggu kosong pada pagi hari pada saat aktivitas perkantoran baru dimulai. Beberapa nasabah yang baru pertama kali bertransaksi pada obyek penelitian ini atau nasabah yang sudah lama tidak melakukan transaksi, langsung mengambil tempat duduk, tanpa terlebih dahulu mengambil tiket antrean. Setelah menyadari bahwa disamping kiri terdapat mesin tiket antrean, nasabah tersebut baru mengambil tiket untuk kemudian duduk kembali menunggu panggilan teller atau costumer service.
Penuhnya kursi tunggu, mendorong nasabah melakukan penyimpangan kedua seperti diilustrasikan pada gambar $5 \# 2$, yaitu dengan mencari zona tunggu lain. Berada di luar gedung menjadi satu pilihan, selain alasan privacy, juga karena pengguna ruang terlihat lebih leluasa melakukan personal activity lain seperti merokok atau menelpon. Ketika ada nasabah yang mulai meninggalkan zona tunggu, nasabah yang menunggu di luar baru masuk, menggantikan posisi duduknya.

Penyimpangan yang lain adalah akibat adanya kecenderungan nasabah memilih duduk di baris luar (gambar 5\#3 - kursi arsir hitam), supaya pada waktu giliran pemanggilan oleh teller atau customer service, mudah dan tidak mengganggu orang lain. Demikian pula saat kursi favorit (kursi arsir hitam) ditinggalkan oleh pengguna, nasabah lain, baik yang duduk diluar kursi arsir hitam atau yang berdiri, berusaha untuk menggantikan posisi tersebut.

Terjadi crowding yang diakibatkan selain oleh kecenderungan diatas, juga karena sempitnya jarak antar tempat duduk depan dan belakang, yang hanya $300 \mathrm{~mm}$. Nasabah enggan untuk duduk di sisi dalam karena sifat dasar manusia yang tidak ingin mengganggu orang lain, (dalam hal ini adalah mengganggu orang yang duduk di kusi favorit) dan egoisme manusia yang enggan bersinggungan dengan orang lain, pada saat masuk untuk duduk dan pada saat keluar dari tempat duduk. Ketika jumlah nasabah yang berdiri pada zona publik disamping kursi tunggu mulai banyak (lebih dari 3 orang), sebagian nasabah mulai bisa menerima keadaan crowding tersebut, dengan melakukan adaptasi, yaitu dengan cara menduduki ruang tunggu sisi dalam (gambar

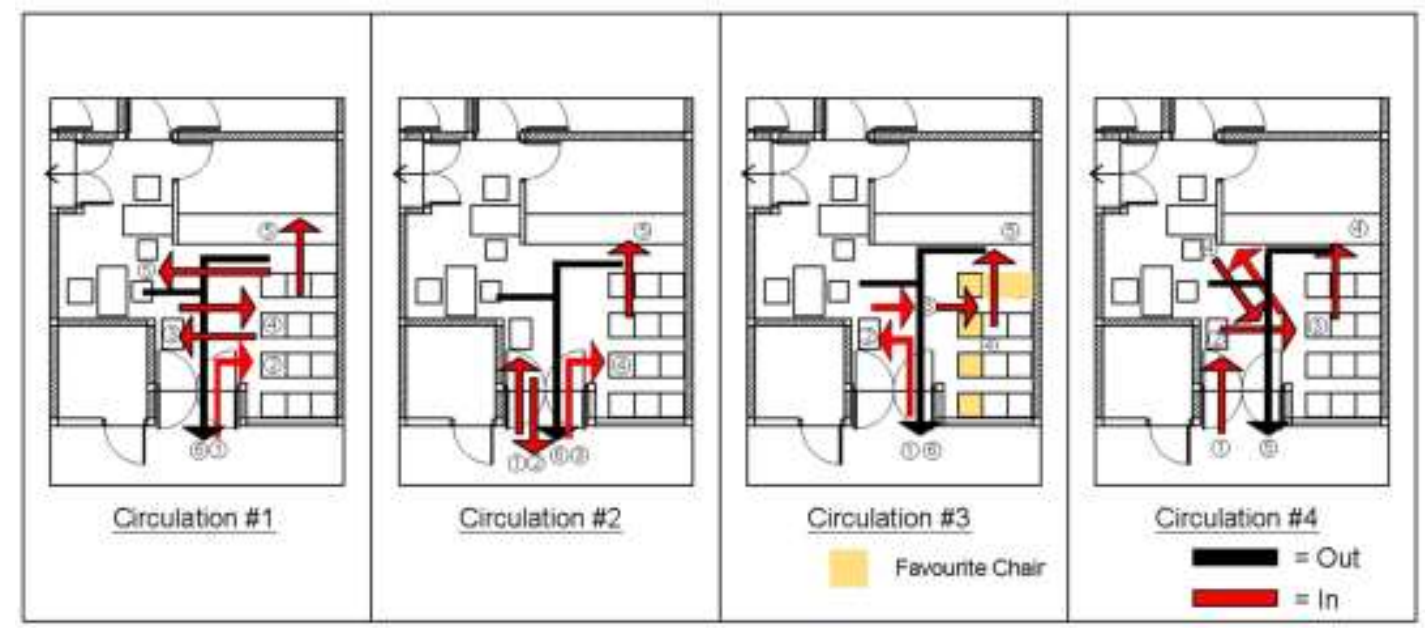

Gambar 5. Realita Sirkulasi Akibat Lay Out

Sumber: Analisis Pribadi (2019) 
5\#3 - kursi tanpa arsir) walaupun dengan resiko akan bersinggungan dengan nasabah lain, pada saat mau duduk dan mau keluar dari tempat duduk. Kondisi ini bisa dilihat pada gambar 5\#3.

Penyimpangan ke 4 terjadi akibat Customer service yang hanya menyediakan 1 kursi tamu. $\mathrm{Hal}$ ini menyebabkan nasabah yang memerlukan pendampingan, melakukan penyimpangan sirkulasi, yaitu bolak-baliknya pendamping dari kursi tunggu atau pendamping yang harus berdiri disamping kursi tamu seperti terlihat pada gambar $5 \# 4$.

Sesuai dengan teori yang dikemukakan oleh hakim, 1987, maka variabel sirkulasi yang terdapat pada obyek penelitian adalah:

a. Dimensi Jalur Sirkulasi. Sirkulasi publik sudah dirancang agar dapat mengakomodasi kebutuhan banyak orang, dari berbagai rentang usia namun kurang memperhatikan faktor keterbatasan (disable).

b. Kejelasan Orientasi. Kurang adanya kejelasan orientasi sirkulasi, dimana ini mempengaruhi kenyamanan sirkulasi pengguna yang cenderung tidak sesuai rencana.

c. Penerapan Elemen Sirkulasi (Signage). Tidak adanya elemen pembentuk signage seperti text, warna pembeda, simbol, panah dan cahaya pengarah, menyebabkan terjadinya dis-orientasi pengguna.

\section{Posisi dan Dimensi Furnishing}

Ada standard maximal dan minimal pada dimensi furnishing yang disyaratkan yang bisa di pakai sebagai acuan arsitek dalam menentukan pilihan untuk karyanya. Untuk ruangan dengan ukuran yang sempit dan kapasitas pengguna yang cukup banyak, penggunaan furnishing dengan ukuran minimal dan pemilihan jenis furniture yang simple, harus dijadikan pertimbangan desain. Gambar 6, menunjukkan letak, jumlah dan dimensi furnishing hasil observasi pada obyek penelitian.

Dari hasil Observasi pada obyek penelitian, terdapat tujuh permasalahan yang timbul, terkait dengan besarnya dimensi furnishing dan jarak antar furnishing, seperti diilustrasikan pada gambar 7 .

Permasalahan perilaku pengguna property pertama sebagai akibat besarnya dimensi

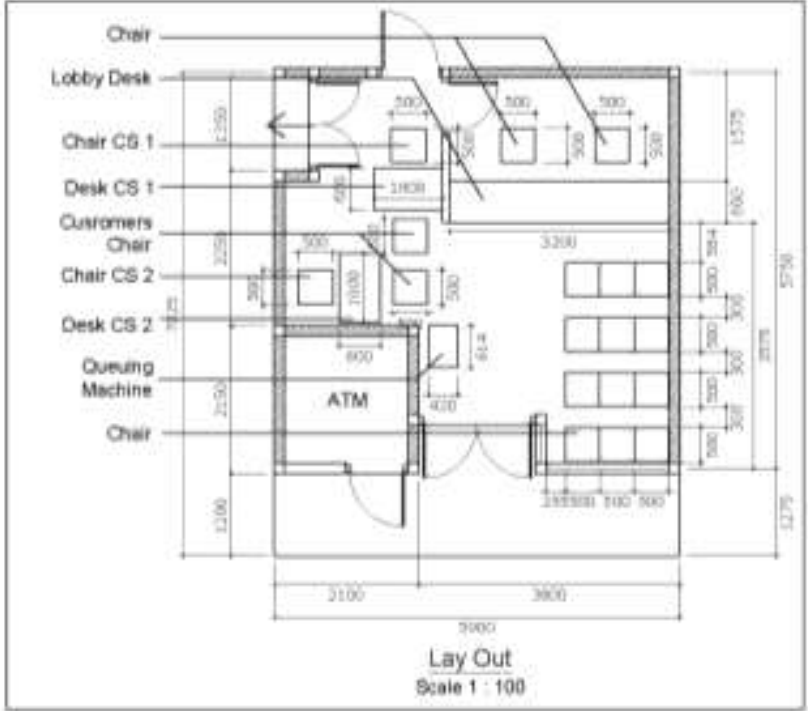

Gambar 6. Posisi dan Dimensi Furnishing Sumber: Analisis Pribadi (2019)

furnishing dan dekatnya jarak antar furnishing pada obyek penelitian adalah kecenderungan perilaku nasabah dimana nasabah yang datang lebih dahulu, memilih duduk pada deret sisi terluar (arsir kuning), seperti diilustrasikan pada gambar 7\#1.

Jika kursi favorit (arsir kuning) sudah terisi penuh, sebagian nasabah memilih untuk berdiri di samping kursi tunggu, menunggu nasabah yang duduk di kursi favorit pergi, untuk kemudian menggantikan duduk di kursi favorit, daripada duduk di kursi kosong pada sisi dalam. Ketika sudah terdapat dua atau tiga orang yang berdiri di samping kursi tunggu, sebagian nasabah yang lain, justru memilih menjauh menunggu di luar gedung, selain karena crowding, alasan lain adalah nasabah terlihat lebih bebas melakukan personal activity seperti telpon atau merokok.

Permasalahan kedua terkait dimensi dan jarak furnishing, seperti terlihat pada gambar 7\#2, dimana jika kursi favorit (arsir kuning), sudah penuh, nasabah berikutnya yang ingin duduk di kursi kosong pada sisi dalam, harus melewati orang yang duduk di kursi favorit. Dengan jarak kursi depan dan kursi belakang yang hanya $300 \mathrm{~mm}$, maka privacy nasabah yang duduk pada kursi favorit akan terganggu. Ini bisa dilihat dari perilaku nasabah yang duduk di kursi favorit, yang harus merapatkan kaki untuk memberi jalan kepada nasabah yang mau duduk pada kursi kosong pada sisi dalam supaya tidak terjadi saling bersentuhan. 


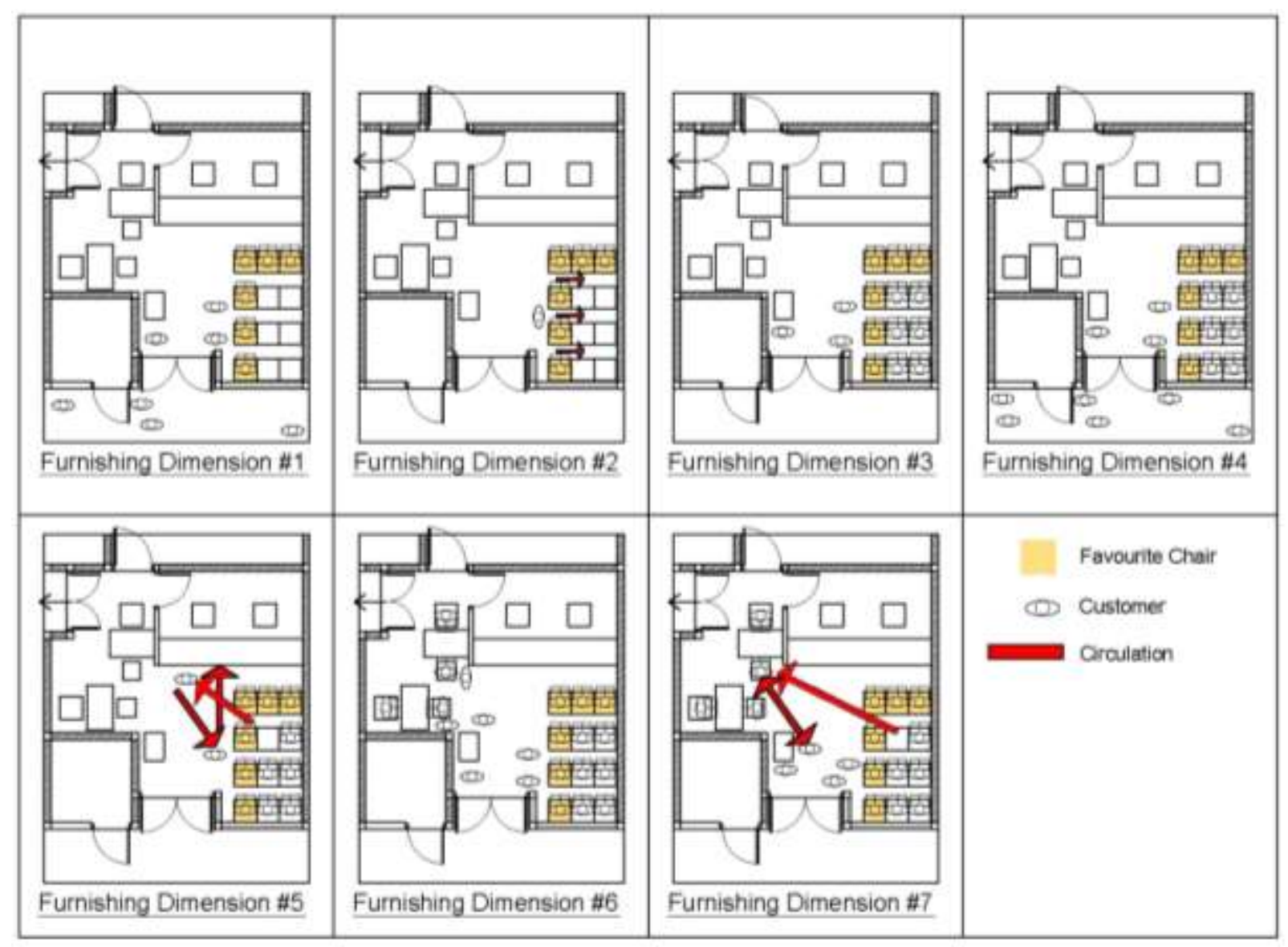

Gambar 7. Penyimpangan Akibat Dimensi Furnishing Sumber: Analisis Pribadi (2019)

Permasalahan ketiga pada obyek penelitian sehubungan dengan dimensi dan jarak antar furnishing seperti terlihat pada gambar 7\#3 adalah penuhnya kursi tunggu yang hanya berjumlah 12 buah. Hal ini menyebabkan nasabah yang tidak kebagian kursi memilih berdiri di dalam ruangan, di samping kursi tunggu, agar tetap bisa mendengarkan informasi atau panggilan dari teller atau customer service. Aktivitas ini dilakukan untuk menunggu nasabah yang berdiri meninggalkan tempat duduk dan menggantikan posisinya. Kondisi ini terjadi pada beberapa nasabah, sehingga jumlah nasabah yang berdiri di samping kursi tunggu menjadi banyak.

Permasalahan keempat yang teridentifikasi pada obyek penelitian terkait dimensi dan jarak furnishing seperti terlihat pada gambar $7 \# 4$ adalah mirip dengan kondisi pada permasalahan tiga diatas, dimana kursi tunggu penuh dan sudah ada beberapa nasabah yang berdiri menunggu di samping kursi tunggu di dalam ruangan. Namun nasabah lain yang baru datang merasa crowding dan memilih menunggu di luar gedung, supaya tetap bisa melakukan aktivitas lain seperti menelpon dan merokok, sambil sesekali menengok kedalam ruangan. Jika sudah mulai berkurang, nasabah tersebut baru memasuki ruangan untuk menunggu di bagian dalam dengan berdiri disamping kursi tunggu, menunggu salah satu kursi kosong untuk diduduki.

Permasalahan kelima yang terjadi pada obyek penelitian, terkait dengan dimensi furnishing dan jarak antar furnishing seperti terlihat pada gambar 7\#5 adalah nasabah yang sudah mendapatkan panggilan teller untuk melakukan transakasi, namun sambil menunggu proses yang dilakukan oleh teller, nasabah diminta untuk kembali ke kursi tunggu menunggu panggilan teller selanjutnya. Namun dengan alasan akses jalan yang sempit, agar tidak mengganggu nasabah lain, dan mempercepat pemanggilan kembali, nasabah tersebut memilih untuk tetap berdiri di samping kursi tunggu. Jika pada samping kursi tunggu sudah ada beberapa nasabah yang berdiri menunggu karena tidak kebagian kursi dan terjadi crowding, maka nasabah ini 
terpaksa menerima kondisi crowding ini dengan menjadi bagian darinya.

Permasalahan keenam yang terjadi pada obyek penelitian, seperti terlihat pada gambar 7\#6 adalah nasabah yang memerlukan pendamping dipanggil oleh customer service. Hanya saja karena kursi tamu yang disediakan pada customer service hanya satu. Sehingga pendamping harus berdiri disamping kursi tamu customer service. Jika pada samping kursi tunggu sudah ada beberapa nasabah yang berdiri menunggu karena tidak kebagian kursi dan terjadi crowding, maka pendamping nasabah ini terpaksa menerima kondisi crowding ini dengan menjadi bagian darinya.

Permasalahan terakhir yang didapati pada obyek penelitian, seperti terlihat pada gambar 7\#7. Kondisinya seperti pada kondisi permasalahan 6 , dimana pendamping justru bolak balik dari tempat duduk menuju kursi Customer Service hanya saat dibutuhkan oleh customer service saja. Tetapi untuk memudahkan pergerakan, pendamping memilih berdiri di samping kursi tunggu, daripada harus kembali duduk di sisi dalam, mengingat akses untuk keluar masuk ke tempat duduk bagian dalam (bukan tempat duduk favorit) cukup sempit dan mengganggu nasabah yang lain. Kondisi ini menyebabkan jumlah nasabah yang berdiri menjadi bertambah, jika sebelumnya sudah terdapat nasabah lain dengan alasan tertentu berdiri disamping kursi tunggu.

Secara garis besar, inti dari permasalahan yang timbul bisa dilihat karena:

a. Sempitnya akses menuju tempat duduk, karena dimensi kursi pada ruang tunggu cukup besar dan jarak antar kursi terlalu sempit

b. Jumlah kursi yang sedikit karena pemilihan ukuran kursi yang bukan menggunakan ukuran minimal

c. Sistem desain yang mengkondisikan nasabah melakukan antrean dalam posisi duduk, bukan berdiri, sehingga furnishing (dalam hal ini kursi) memakan tempat.

\section{Analisis Data}

Pengamatan kenyamanan sirkulasi pengguna pada obyek penelitian meliputi sirkulasi pengguna sebagai respon terhadap permasalahan lay out dan sirkulasi pengguna sebagai respon terhadap dimensi furnishing. Respon pengguna terhadap lay out ditunjukkan dengan indikator sirkulasi pengguna as plan atau sesuai rencana, sirkulasi pengguna sesuai case \#1, case \#2, case \#3 dan case \#4. Sedangkan respon pengguna terhadap dimensi furnishing ditunjukkan dengan indikator aktivitas nasabah as plan atau sesuai rencana, aktivitas nasabah sesuai penyimpangan \#1, penyimpangan \#2, penyimpangan \#3, peyimpangan \#4, peyimpangan \#5, penyimpangan \#6 dan penyimpangan \#7.

Prosentasi besarnya aktivitas sirkulasi pengguna sebagai respon terhadap lay out tata ruang-dalam terlihat pada gambar 8 . Besarnya prosentase nasabah yang melakukan sirkulasi sesuai rencana lay out tata ruang-dalam pada obyek penelitian (AP) adalah sebesar $23 \%$, sisanya sebesar $77 \%$ merupakan aktivitas yang tidak sesuai dengan perencanaan (C1, C2, C3 dan C4). Penyimpangan sirkulasi tertinggi terjadi pada case \#3 (C3) sebesar $32 \%$ dan penyimpangan sirkulasi terendah terjadi pada case \#1 (C1) dan 4 (C4) sebesar 9\%. Kesesuaian sirkulasi terhadap rencana desain tata ruang-dalam pada aspek lay out, menunjukkan adanya kenyamanan sirkulasi, sedangkan ketidak-sesuaian sirkulasi terhadap rencana desain tata ruang-dalam pada aspek lay out menunjukkan adanya ketidaknyamanan sirkulasi pengguna terhadap seting ruang tunggu pada obyek penelitian.

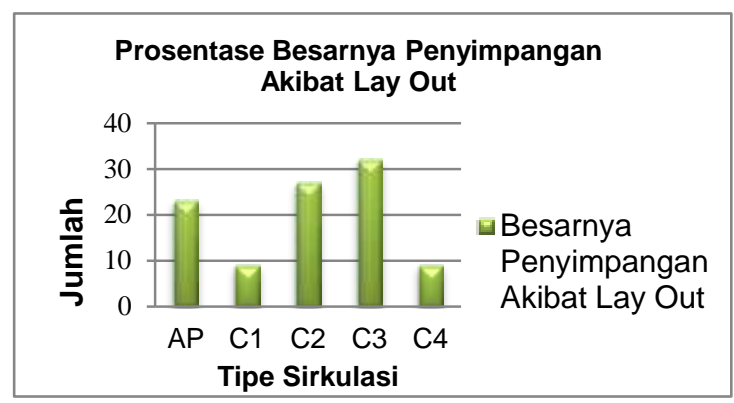

Note:

$\begin{array}{ll}\text { AP }=\text { As Plan } & \text { C3 }=\text { Circulation \#3 } \\ \text { C1 }=\text { Circulation \#1 } & \text { C4 }=\text { Circulation \#4 } \\ \text { C2 }=\text { Circulation \#2 } & \end{array}$

Gambar 8. Besar Penyimpangan Akibat Lay out Sumber: Analisis Pribadi (2019) 
Untuk prosentasi besarnya aktivitas sirkulasi pengguna sebagai respon terhadap dimensi furnishing tata ruang-dalam seperti terlihat pada gambar 9.

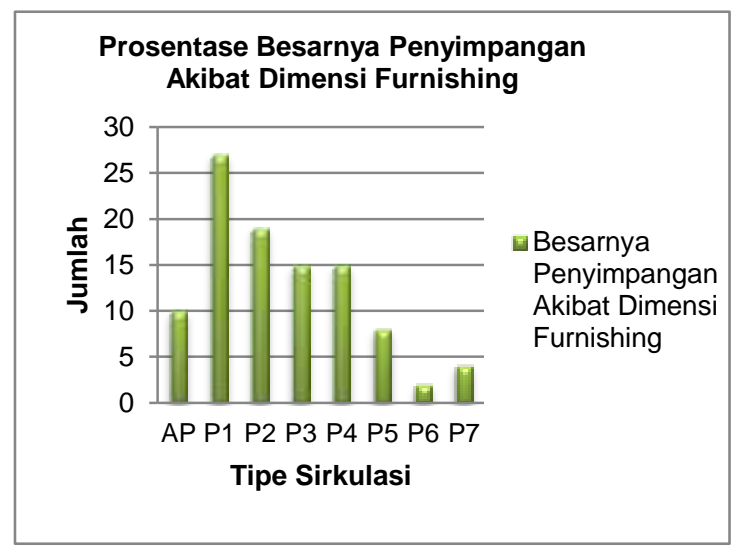

$\mathrm{AP}=$ As Plan

$\mathrm{P} 1=$ Furnishing Dimension \#1

$\mathrm{P} 2=$ Furnishing Dimension \#2

P3 = Furnishing Dimension \#3

$\mathrm{P} 4=$ Furnishing Dimension \#4

P5 = Furnishing Dimension \#5

P6 = Furnishing Dimension \#6

P7 = Furnishing Dimension \#7

Gambar 9. Besar Penyimpangan Akibat Dimensi Furnishing

Sumber: Analisis Pribadi (2019)

Besarnya prosentase nasabah yang melakukan sirkulasi sesuai rencana berdasarkan dimensi furnishing tata ruangdalam pada obyek Penelitian (AP) hanya sebesar $10 \%$, sisanya sebesar $90 \%$ merupakan sirkulasi yang tidak sesuai dengan perencanaan arsitek (P1, P2, P3, P4, P5, P6 dan P7). Penyimpangan sirkulasi tertinggi terjadi pada penyimpangan 1 (P1) sebesar $27 \%$ dan penyimpangan sirkulasi terendah terjadi pada penyimpangan 6 (P6) sebesar $2 \%$. Kesesuaian sirkulasi terhadap rencana desain tata ruang-dalam pada aspek dimensi furnishing, menunjukkan adanya kenyamanan sirkulasi, sedangkan ketidak-sesuaian sirkulasi terhadap rencana desain tata ruang-dalam pada aspek dimensi furnishing menunjukkan adanya ketidak-nyamanan sirkulasi pengguna.

Dan secara umum, hasil pengamatan tingkat kenyamanan sirkulasi pada obyek penelitian terhadap desain global tata ruang-dalam bisa dilihat pada gambar 10 .

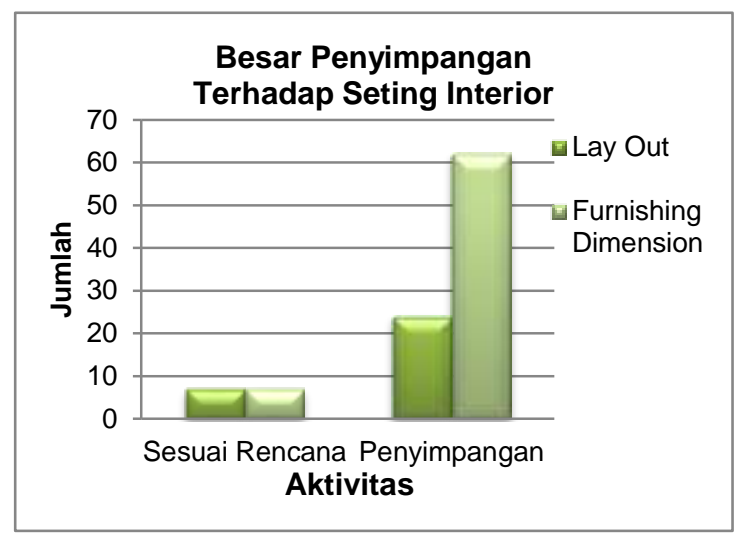

Gambar 10. Besar Peyimpangan Terhadap Seting Interior

Sumber: Analisis Pribadi (2019)

Dari data diatas, didapati bahwa hampir semua elemen seting tata ruang-dalam yang diteliti yaitu lay out dan dimensi furnishing menunjukkan adanya ketidakseuaian perilaku/aktivitas pengguna ruang terhadap desain tata ruang-dalam. Kesesuaian aktivitas terhadap rencana desain tata ruang-dalam global, menunjukkan adanya kenyamanan sirkulasi, sedangkan ketidaksesuaian aktivitas terhadap rencana desain tata ruang-dalam global, menunjukkan adanya ketidaknyamanan sirkulasi pada pengguna. Besarnya ketidaknyamanan sirkulasi akibat aspek dimensi furnishing adalah sebesar 62\%, sedangkan besarnya ketidaknyamanan sirkulasi akibat aspek lay out sebesar $40 \%$. Dimana baik untuk aspek lay out maupun dimensi furnishing tingkat kenyamanan sirkulasi hanya sebesar masing-masing $7 \%$.

\section{KESIMPULAN DAN SARAN}

\section{Kesimpulan}

Dari pembahasan diatas, kesimpulan yang bisa diambil adalah:

1. Secara umum, seting tata ruang-dalam berpengaruh terhadap kenyamanan dan ketidaknyamanan sirkulasi pengguna property. Seting tata ruang-dalam yang salah menyebabkan banyaknya perilaku/aktivitas pengguna property yang tidak sesuai dengan perencanaan/desain awal.

2. Aspek lay out dan dimensi furnishing pada seting interior mempengaruhi secara significant terhadap kenyamanan sirkulasi pengguna ruang.

3. Semakin tinggi tingkat kenyamanan sirkulasi pada seting tata ruang-dalam, maka semakin tinggi pula tingkat kesesuaian aktivitas pengguna property terhadap rancangan arsitek. 
4. Besarnya ketidaksesuaian sirkulasi terhadap desain tata ruang-dalam secara global menunjukkan perlu adanya redesign tata ruang-dalam pada obyek penelitian, yang bisa mengakomodir semua permasalahan yang ada.

\section{Saran Pemecahan}

Hal mendasar yang menjadi rekomendasi desain baru adalah:

1. Penggunaan dimensi furnishing harus diperhitungkan, terutama pada seting ruang tunggu dengan besaran ruang minimal. Penggunaan dimensi minimal bisa dijadikan alternatif, disamping pemilihan jenis dan bentuk furnishing yang sederhana dan simple.

2. Pengurangan furnishing dan pengaturan jarak furnishing sesuai touch zone area serta penggantian sistem antrean dari sistem duduk menjadi sistem antre berdiri, akan lebih banyak menampung pengguna, karena touch zone area berdiri yang lebih sedikit dibandingkan dengan touch zone area posisi duduk.

3. Pemanfaatan side entry untuk mengurangi crowding pada area depan pintu, serta memastikan sirkulasi sesuai urutan aktivitas

4. Perlunya signage yang jelas, tentang tata urutan bertransaksi terutama bagi nasabah yang baru pertama kali melakukan transaksi pada ruang tunggu bank secara umum.

Contoh Pemecahan lay out ruang tunggu, bisa dilihat pada gambar dibawah ini.

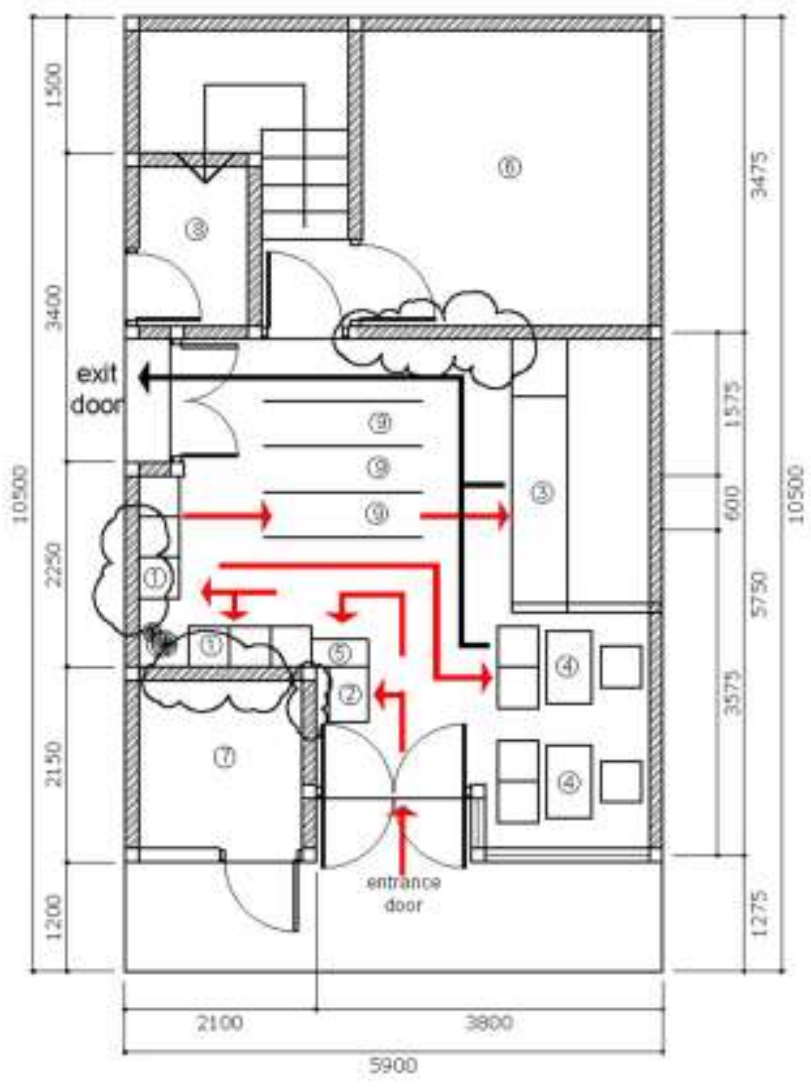

Recomendation Lay out
SIPKUALSI

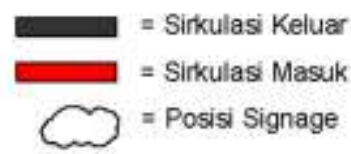

KETERANGAN :

1. Ruang Tunggu

2. Ruang Ticketing

3. Ruang Locket

4. Ruang Customer Servise

5. Meja tulis \& brosur

6. Gudang

7. ATM

8. Toilet

9. Jalur antrian

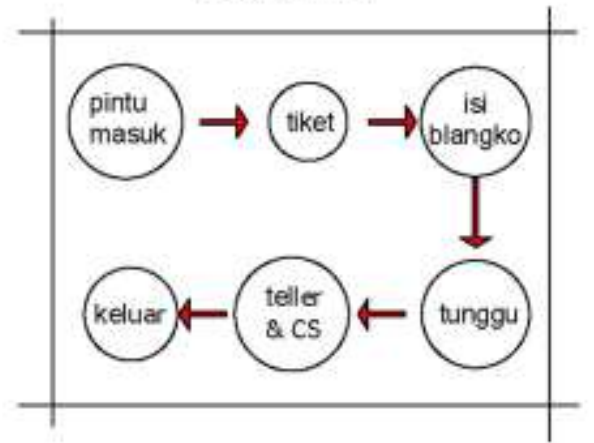

Gambar 11. Recomendasi lay out

sumber: Analisis Pribadi (2019) 


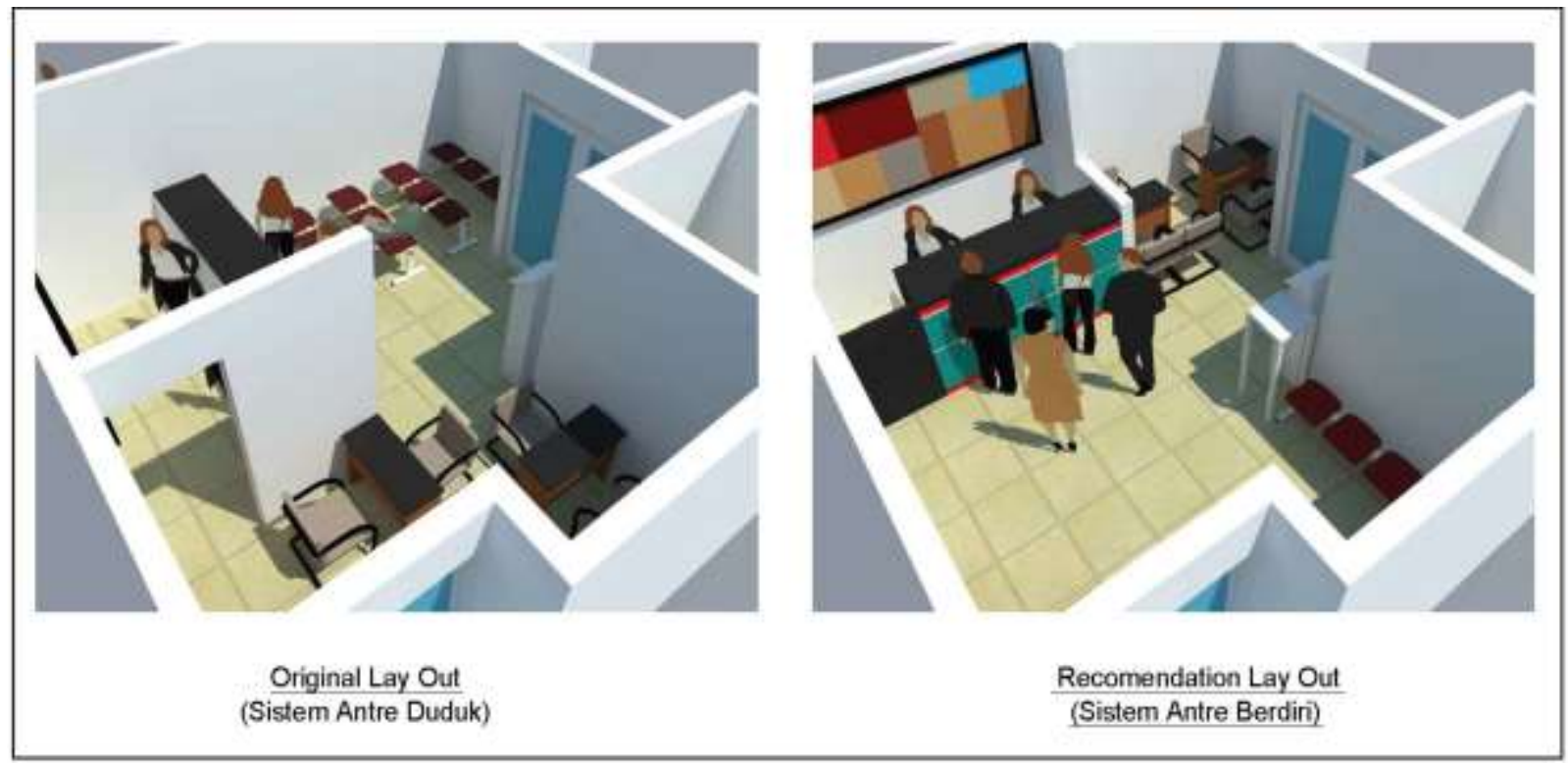

Gambar 12. Perbandingan Original dan Rekomendasi lay out sumber: Analisis Pribadi (2019)

\section{DAFTAR PUSTAKA}

Adhitama, M. S. (2013). Faktor Penentu Setting Fisik Dalam Beraktivitas Di Ruang Terbuka Publik, "Studi Kasus Alun - Alun Merdeka Kota Malang." Jurnal RUAS, 11(2).

Atkinson, R. (1983). The Hidden Dimension. New York: Double day.

Ching, F. D. (1979). Arsitektur: Bentuk Ruang dan Susunannya. Erlangga.

Hakim, R. (2012). Unsur Perancangan dalam Arsitektur Lansekap. Jakarta: Bumi Aksara.

Harris, C. M. (1975). Dictionary of Arsitektur and Construction. Mc Grraw: Hill Book Comp.

Haryadi, \& Setiawan, B. (1995). Arsitektur Lingkungan Dan Perilaku. Yogyakarta: Direktorat Jendral Pendidikan.

Malkin, J. (1992). Hospital Interior Architecture, Creating Healing Environments for Special Patient Populations. New York: Van Nostrand Reinhold.

Neufert, E. (2002). Data Arsitek (33rd ed.). Jakarta: Erlangga.

Oborne, D. J. (1995). Ergonomic at Work: Human Factors in Design and Development. West Sussex. England: John Wiley \& Sons Ltd.

Preiser, W. F. E. ... White, E. T. (1993). Post Occupancy Evaluation, Van Nostrand Reinhold Co. New York: Van Nostrand Reinhold.

Singarimbun, M. (1992). Metode Penelitian Survey. Jakarta: Pustaka LP3ES.
Suptandar, P. (1982). Interior Design. Jakarta: Usakti.

Weisman, J. (1981). Modeling Environmental Behavior System, Journal of Man Environmental Relation. Pensilvania. 
